\section{A BASIC factorial ANOVA program with a repeated-measures option for microprocessors}

\author{
HAROLD R. STRANG \\ University of Virginia, Charlottesville, Virginia 22903
}

This BASIC program, designed for microprocessors, offers complete input, analysis, and tabular output functions for either two-way or three-way analysis of variance (ANOVA) for completely randomized (CRF) or randomized block (RBF) factorial designs (see Kirk, 1968, pp. 171-187, 237-243).

Input. Via keyboard input, the user selects the number of treatments, the number of levels per treatment, whether or not the design has repeated measures, and the number of subjects per cell. Using an OSI Challenger II microprocessor with $48 \mathrm{~K}$ of RAM, it is possible to select any two- or three-treatment design that has a total cell count not in excess of 32 . For example, the program can accommodate a 4 by 8 or a 2 by 4 by 4 design. The subject-per-cell limit is 50 .

Two data entry options are available. The user may key each entry into the terminal. If, however, the data are already stored on a floppy disk, the user inputs the appropriate file name, which triggers the transfer of the data into active memory. Analysis and output functions follow immediately.

Output. After data analysis, a video display informs the user that, in addition to receiving output on the terminal's video monitor, he can also elect to receive a hard-copy printout. A single keystroke determines output mode. Initial output consists of a listing of cell means and standard deviations, followed by an ANOVA summary listing. Table 1 presents a hard-copy output of a 2 by 2 ANOVA with repeated measures produced by a printer with a 132-character/line capacity. The user also has the option for outputting a listing (not included in Table 1) of the sums of Xs for all levels of all treatments as well as for all possible treatment interactions. After any hard-copy output, the user may request additional printouts of that listing before continuing.

Language and Requirements. Since the program is written in BASIC, it should be adaptable to most $48 \mathrm{~K}$ microprocessors with minor changes in several output addresses. By changing several dimension statements within the program, users having less than $48 \mathrm{~K}$ of RAM can reduce cell and/or subject limits and thus adjust the program to available RAM. For users not

RESULTS OF ANOVA ANALYSIS

TABLE OF MEANS AND SD'S (N PER CELL $=4)$

A 1 B $1 \quad 3.75$

( 1.5$)$

A 1 B 24

(.82)

A 1 B 37

(.82)

A 1 B $4 \quad 8$

(.82)

A 2 B $1 \quad 1.75$

A 2 B $2 \quad 3$

$(.82)$

A 2 B $3 \quad 5.5$

$(.58)$

A 2 B $4 \quad 10$

(.82)

ANALYSIS OF VARIANCE TABLE

\begin{tabular}{|c|c|c|c|c|}
\hline $\begin{array}{l}\text { REPEATED } \\
\text { SOURCE }\end{array}$ & $\begin{array}{l}\text { N INDEP VAF } \\
\text { SS }\end{array}$ & $\mathrm{DF}$ & MS & $\mathrm{F}$ \\
\hline A & 3.12500048 & 1 & 3.12500048 & 4.95283104 \\
\hline B & 194.5 & 3 & 64.8333335 & 102.754719 \\
\hline $\mathrm{AB}$ & 19.374999 & 3 & 6.45833302 & 10.2358487 \\
\hline RESIDUAL & 13.2499998 & 21 & .63095237 & \\
\hline
\end{tabular}

Note-These are sample data taken from Kirk (1968, pp. 239-240). 


\section{STRANG}

having OSI microprocessors, appropriate file-access commands must be substituted.

Limitations. In its present form, the program does not execute unequal-cell analyses, and the repeatedmeasures option operates on an all-or-none basis for all treatments.

Availability. A complete listing of this program can be obtained from the author for the cost of reproduction. Also available are several less flexible factorial ANOVA programs that allow for unequal numbers of subjects per cell or the application of repeated measures to one treatment but not to others in the same design. The author's address is 140 Ruffner Hall, University of Virginia, 405 Emmet Street, Charlottesville, Virginia 22903.

\section{REFERENCE}

KıкK, R. E. Experimental design: Procedures for the behavioral sciences. Belmont, Calif: Brooks/Cole, 1968.

(Accepted for publication June 13, 1980.) 